\title{
Ice temperature and high geothermal flux at Siple Dome, West Antarctica, from borehole measurements
}

\author{
HERMANN ENGELHARDT \\ Division of Geological and Planetary Sciences, Caltech 100-23, Pasadena, California 91125, U.S.A. \\ E-mail:engel@caltech.edu
}

\begin{abstract}
A vertical temperature profile through the West Antarctic ice sheet (WAIS) at the summit of Siple Dome reveals an elevated geothermal flux. This could be the root cause for the existence of a dynamic ice-stream system in theWAIS. Siple Dome is still frozen on its bed, but adjacent ice streams have bed temperatures at the pressure-melting point of ice. Although present-day temperature increases due to climatic change do not have an immediate effect on the basal conditions that control the velocity of the ice, indirect effects like a rapid disintegration of the floating ice shelves or additional meltwater input at the surface could give rise to speed-up of the ice streams with an ensuing rise in sea level. Ongoing melt at the base of the ice and changes at the margins will allow continued rapid flow of the ice streams with a possibility of disintegration, within a relatively short period of time, of at least part of the WAIS.
\end{abstract}

\section{INTRODUCTION}

The West Antarctic ice sheet (WAIS) contains 11 major ice streams moving at speeds 10-100 times faster than the surrounding ice, with the exception of the lower part of Kamb Ice Stream (former Ice Stream C) that slowed considerably about 150 years ago (Retzlaff and Bentley, 1993). These are speeds much higher than can be explained by internal deformation of the ice alone. Additional mechanisms, like basal sliding and basal bed deformation, have to contribute in order to account for the remarkable dynamics of these ice currents. For these mechanisms to become active, the base of the ice streams has to be at the pressure-melting point and well lubricated by water at high pressure. The contribution from sliding can be substantial, sometimes close to $100 \%$ of total speed (Engelhardt and Kamb, 1998). The causes for melting or freezing conditions at the base are: (a) the climate history at the surface, namely temperature and snow accumulation; (b) the thermal and flow history of the ice, namely internal and basal frictional heating, heat conduction and heat advection; and (c) the geothermal flux.

The purpose of this work is to present measurements of the temperature profiles in the ice at Siple Dome (SD), especially the basal temperature gradient that reflects the geothermal flux. The latter can be measured unequivocally only at a place where the ice was frozen to the bed for a long time, so that the freezing front has penetrated deep into bedrock and sources of latent heat from water are absent. The best location for such measurements on the WAIS is at the summit of SD $\left(81.658^{\circ} \mathrm{S}, 148.809^{\circ} \mathrm{W}\right.$; $601 \mathrm{~m}$ a.s.l.) (Fig. 1). SD is the largest interstream ridge, located between Kamb Ice Stream and Bindschadler Ice Stream (former Ice Stream D). The ice at SD is moving very slowly, by internal deformation, of the order of $0-10 \mathrm{ma}^{-1}$. Precisely at the summit, the horizontal speed is zero because the surface slope and therefore the driving stress is zero. Although the

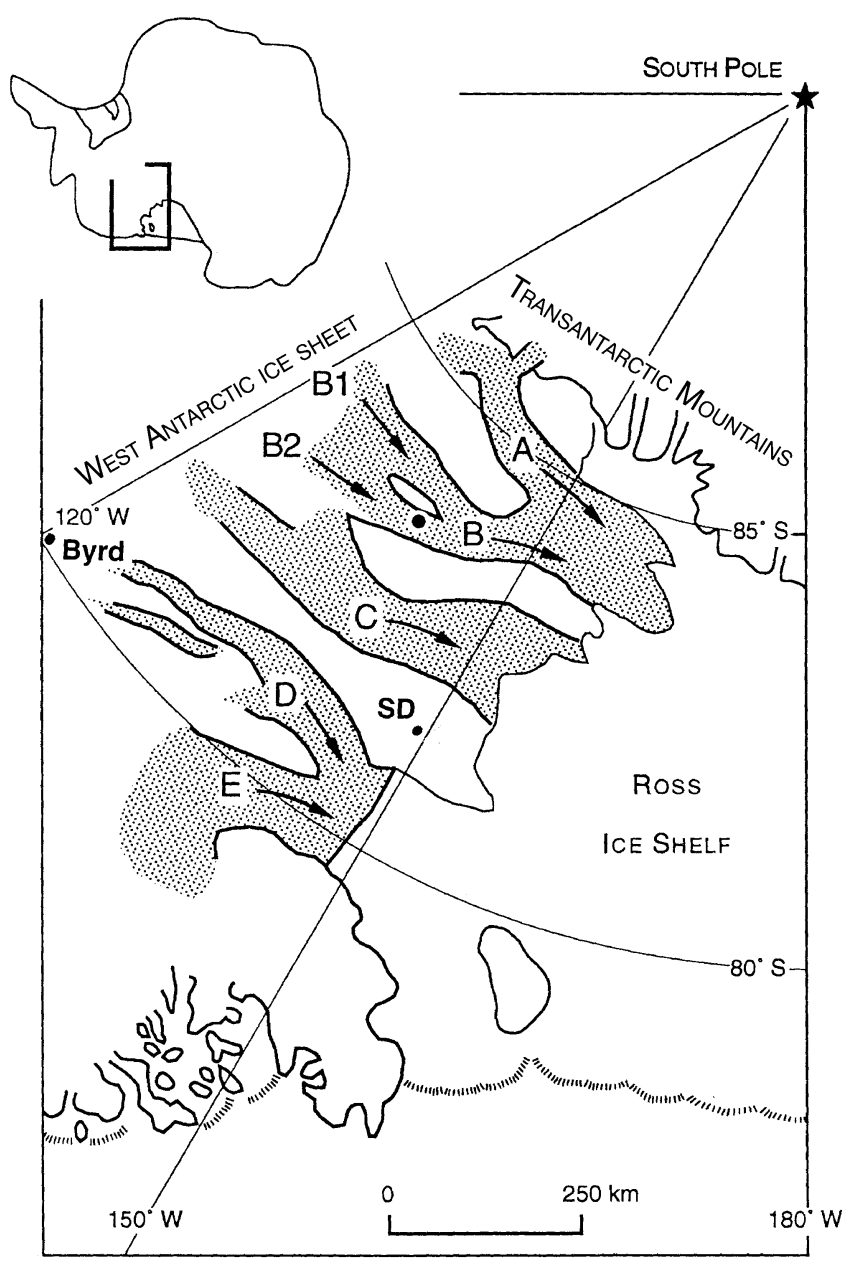

Fig. 1. Five major West Antarctic ice streams flow from the WAIS into the Ross Ice Shelf. SD is part of an interstream ridge between Kamb Ice Stream $(C)$ and Bindschadler Ice Stream (D). Mercer Ice Stream (A), Whillans Ice Stream (B), and MacAyeal Ice Stream ( $E$ ) also belong to the WAIS system. The dots indicate borehole locations. 
exact location of the summit may have shifted with time due to changing accumulation patterns, it is assumed that the central part of SD has existed in the same vicinity since the last ice age or longer (Nereson and others, 1998).

The absence of, or very low, velocity at or near the summit of SD removes shear heating, heat advection and basal friction as sources in the heat-balance equation, providing a much simplified case of the general heat-flow problem, and also making interpretation less complicated. Previous measurements of temperature profiles from the WAIS surface to the bed were made at Byrd Station and at Whillans Ice Stream (Gow and others, 1968; Engelhardt and Kamb, 1993). Other temperature measurements were taken on the Ross Ice Shelf at drill site J9 (MacAyeal and Thomas, 1979) and Crary Ice Rise (Bindschadler and others, 1990). However, in most boreholes, the bottom temperature is fixed at the pressure-melting point. In these cases, the water available at the bed or in the till provides sources of latent heat. The ice is flowing and produces shear heating within the ice and at the base. So many heat sources in addition to the geothermal flux make the separation of the geothermal contribution impossible. In contrast, SD is frozen to its base so that the same heat flux in the rock beneath the ice can flow through the ice-rock interface into the ice. Extensive modeling has been done to elucidate the influence of the geothermal flux on the non-steady-state temperature profiles in ice sheets (Robin, 1955, 1976; Jenssen and Radok, 1961; Lliboutry, 1963; Müller, 1963; Weertman, 1968; Budd and others, 1976; Paterson and Clarke, 1978; Dahl-Jensen and Johnsen, 1986; Ritz, 1987, 1989; Waddington, 1987; Paterson, 1994).

\section{MEASUREMENTS}

To measure the vertical temperature profile through the ice at the summit of SD during the 1997/98 field season, we drilled two boreholes specifically for this purpose, one to the bed at $1004.6 \mathrm{~m}$ depth, and a shallow one to $120 \mathrm{~m}$ depth, using the Caltech hot-water drilling system that allows completion of a $1000 \mathrm{~m}$ deep, $10 \mathrm{~cm}$ diameter borehole in 16 hours. Forty additional boreholes were drilled for the measurement of vertical strain rates (Zumberge and others, 2002).

During and after drilling, meltwater from the drilling was standing in the boreholes up to a depth of about $27 \mathrm{~m}$ below the surface, which is the depth of the base of the permeable firn layer. As the ice-sheet bed was reached, the hot-water drill came to a sudden stop, normally indicating a hard rock bed. A subsequent attempt to obtain a soil sample from beneath the bed using a piston corer produced a very small amount of debris but also a smashed cutting head, again showing the hard rock bottom of the borehole. Had the ice been underlain by a layer of glacial rock debris (till) or debris-laden ice as is the case in most boreholes drilled to the base of the ice streams, the hot-water drilling jet would have melted and hydraulically mined through it for several meters, and the piston corer would have picked up a good sample of debris. Also, in ice streams, when the bottom of the ice is reached and the drill encounters a wet bed with a hydraulic system at a water pressure close to the ice overburden pressure, the water level in a $1000 \mathrm{~m}$ borehole would drop from $27 \mathrm{~m}$ to about $100 \mathrm{~m}$ below the surface. Other boreholes reaching the bed in the vicinity of SD did not encounter a soft water-saturated bed either, which is a good indication that at SD the ice sheet is solidly frozen to a rock bed. Such observations allow one to ascertain, before making any temperature measurements, that water sources that could contribute latent heat are not present at or near the ice-bed interface at SD.

To measure borehole temperatures, we use thermistors with temperature-dependent resistances of nominal $5 \mathrm{k} \Omega$ at $25^{\circ} \mathrm{C}$, which were carefully calibrated to $\pm 0.02^{\circ} \mathrm{C}$ for the expected temperature range, using an ice bath and certified precision thermometers. The measured thermistor resistances vs temperatures were least-squares fitted to the Steinhart thermistor equation. Several thermistors recalibrated 2 years later showed no drift. The thermistors are enclosed in pressure-tight tubings closed off with soldered glassmetal electrical feed-throughs. This was necessary to protect the thermistors from being crushed by transient very high pressure during borehole freeze-in and also to avoid possible changes in response to high ice-overburden pressure. The transient pressure increase depends on the freezein rate. We tried to measure the additional pressure, but it exceeded our limit of 27 bar. Previously, we also used unprotected thermistors, but the failure rate was high and unpredictable, while the sealed thermistors survived at least 4 years frozen in the ice at all depths. The thermistors were connected to individual wires of different length bundled together to form thermistor strings. Malfunction of one thermistor would not compromise the whole string.

The thermistor strings were deployed into the waterfilled borehole immediately after completion of drilling. Complete freeze-in occurred in $<1$ day in the upper cold part of the borehole. The thermistor $25 \mathrm{~m}$ above the bottom needed 10 days, and the bottom thermistor was not frozen at the end of the season 2 months later. Thermistor resistances were recorded on a data logger daily, and again 1 and 2 years later in November 1998 and 1999 when the drill site was revisited. It takes a long time, especially near the bed, for the temperature disturbance introduced by hot-water drilling to dissipate. The resistance measurements of frozen-in thermistors can be carried on for several years until the temperature has nearly equilibrated with the environment. Temperature measurements in mechanically drilled boreholes filled with drilling fluids other than water are more difficult because the increasing temperature with depth can cause convective cell mixing and because of the long time required to get the sensor in equilibrium with the surrounding ice temperature, especially when a precision of $0.02^{\circ} \mathrm{C}$ is required. The effect of temperature distortion is especially severe in air-filled shallow boreholes or in crevassed areas where cold-water air pools at the bottom and stays there. Temperatures measured in crevasses were up to $12 \mathrm{~K}$ lower than in the uncrevassed ice (Alley and Bentley, 1988; Harrison and others, 1998).

\section{TEMPERATURE PROFILES AND GEOTHERMAL FLUX}

Final ice temperatures are obtained by plotting temperature vs inverse time and linearly extrapolating to the temperature at inverse time equal to zero (infinite time) (Engelhardt and Kamb, 1993). Most temperatures reached after 2 years come to within a few hundredths of a degree of the extrapolated final value, except the bottom temperature, that needed an extrapolation of $-0.2^{\circ} \mathrm{C}$. 
Table 1. Observed temperatures at discrete heights above bottom of the Siple Dome ice sheet

\begin{tabular}{cc}
\hline Height & Temperature \\
$\mathrm{m}$ & ${ }^{\circ} \mathrm{C}$ \\
\hline 0.7 & -2.54 \\
25.1 & -3.38 \\
49.6 & -4.16 \\
99.3 & -5.63 \\
198.9 & -8.62 \\
298.4 & -11.44 \\
398.3 & -14.18 \\
498.1 & -16.71 \\
597.7 & -19.05 \\
697.2 & -21.08 \\
747.1 & -21.99 \\
796.9 & -22.81 \\
821.6 & -23.19 \\
841.6 & -23.27 \\
860.4 & -23.41 \\
884.0 & -23.94 \\
904.0 & -24.40 \\
924.0 & -24.84 \\
944.0 & -24.75 \\
964.0 & -24.92 \\
984.0 & -24.95 \\
1004.6 & -24.95 \\
\hline
\end{tabular}

The observed temperatures are tabulated in Table 1 and plotted in Figure 2. The bottom temperature is $-2.54^{\circ} \mathrm{C}$, well below the pressure-melting point for clean ice at $-0.7^{\circ} \mathrm{C}$.

The basal temperature gradient of $-32^{\circ} \mathrm{C} \mathrm{km}^{-1}$ could be converted into a heat flux in the ice of $70.4 \mathrm{~mW} \mathrm{~m}^{-2}$ using a thermal conductivity of $2.2 \mathrm{~W} \mathrm{~m}^{-1} \mathrm{~K}^{-1}$ near $0^{\circ} \mathrm{C}$. In the following we want to evaluate how closely this heat flux reflects the geothermal flux.

To elucidate the thermal state of the ice sheet evolving over time, both steady-state and transient calculations were performed. The temperature profile at SD was calculated using a coupled heat- and ice-flow equation that was simplified by the absent horizontal advection and shear heating (Paterson, 1994).

$$
\frac{\partial T}{\partial t}=\kappa \frac{\partial^{2} T}{\partial z^{2}}-v_{z} \frac{\partial T}{\partial z}+\frac{f}{\rho c},
$$

where $T$ is the temperature, $t$ the time, $\kappa$ the thermal diffusivity $\left(1.1 \times 10^{-6} \mathrm{~m}^{2} \mathrm{~s}^{-1}\right), z$ the vertical coordinate, $v_{z}$ the vertical flow velocity of the ice, $f$ the heat from internal deformation, $\rho$ the density of ice and $c$ the heat capacity of ice. $\kappa$ and $c$ vary with temperature according to the parameterization given by Paterson (1994). According to Paterson and Clarke (1978) and Waddington (1987), the influence of the internal deformation from the vertical compression is minimal. Its influence on the basal temperature is about $0.1^{\circ} \mathrm{C}$. We therefore follow the usual practice and drop the last term in our calculations. Instead of a normally assumed linear dependency of $v_{z}$ on $z$, we use a more appropriate dependence derived by Raymond (1983) for the special case of an ice divide like SD summit. This choice is suggested by the shape of the internal layering of radar reflectors, which shows a peculiar bump in the vicinity of the dome.

$$
v_{z}=-a \frac{z^{2}}{h^{2}},
$$

where $a$ is the accumulation rate and $h$ is the ice thickness.

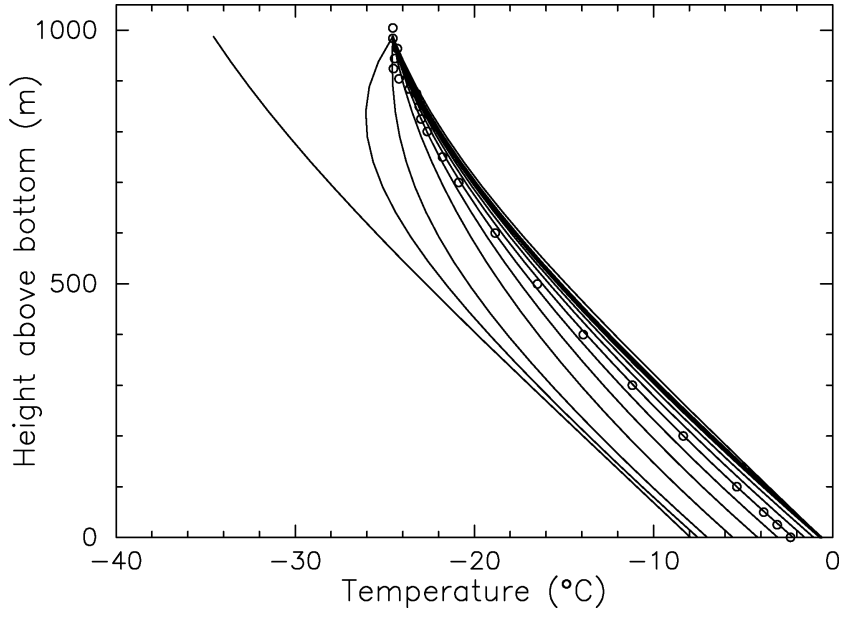

Fig. 2. Observed and calculated temperature profiles. Steadystate profile for present climatic conditions at right, and for ice-age conditions at left. Transient temperature profiles from left to right in two $1 \mathrm{kyr}$ steps and eight $2 \mathrm{kyr}$ steps after a temperature jump at the surface. Observed temperatures lie on the 10 kyr profile.

This type of relationship is confirmed by direct measurements (Zumberge and others, 2002). The steady-state temperature profile $(\partial T / \partial t=0)$ is given by

$$
T-T_{\mathrm{s}}=\left(\frac{\partial T}{\partial z}\right)_{\mathrm{b}}\left(\int_{0}^{z} \mathrm{e}^{-\frac{z^{3}}{l^{3}}} \mathrm{~d} z-\int_{0}^{h} \mathrm{e}^{-\frac{z^{3}}{l^{3}}} \mathrm{~d} z\right),
$$

where

$$
l^{3}=\frac{3 \kappa h^{2}}{a} .
$$

The subscript s designates surface, and b stands for basal values. The averaged mean annual surface temperature is $-24.9^{\circ} \mathrm{C}$ as measured $20 \mathrm{~m}$ below the surface, and the temperature actually measured at the surface, averaged over 2 years from 1997 to 1999 , was $-24.4^{\circ} \mathrm{C}$. The recent accumulation rate is $0.1 \mathrm{~m} \mathrm{a}^{-1}$ (Nereson and others, 2000). First, we tried to fit our borehole temperature measurements to the steady-state equation. This could only be done with an unrealistic accumulation rate of twice the present value. A linear dependence of $v_{z}$ on $z$ would give a better fit, but is not satisfactory for the reasons Raymond (1983) presented. This led to the conclusion that the temperature distribution in the ice is not in steady state, because surface temperature and accumulation changes in the past may not have allowed the temperature to equilibrate fully. In fact the profile will never reach complete equilibrium since climate will keep changing and the ice sheet has such a long-term memory. Daily variations, seasonal changes and annual fluctuations in surface temperature average out fairly quickly in the ice with depth. Usually the ice temperature at $20 \mathrm{~m}$ below the surface is taken as the mean annual surface temperature averaged over decades. Any temperature trend over this short time period is ignored in our calculation. Millennial temperature changes reach much deeper into the ice. They are responsible for the variations in the upper $200 \mathrm{~m}$ in the temperature-depth profile. Using the time-dependent heattransport equation from above and applying a finite-differencing scheme, a sequence of temperature profiles is calculated. The time sequence starts by calculating an initial steady-state temperature profile reaching $4 \mathrm{~km}$ into bedrock by using boundary conditions representing the last ice age 
when, on average, temperatures were about $10 \mathrm{~K}$ lower and the accumulation rate was about $0.05 \mathrm{~m} \mathrm{a}^{-1}$, half the present value. This profile is shown in Figure 2 as the leftmost in the family of profiles. At 10000 years (10 kyr) ago, we let the surface temperature and the accumulation rate jump to the present-day values. The time for the change to take place is short compared to the overall model time, $10 \mathrm{kyr}$ for an ice sheet of $1000 \mathrm{~m}$ thickness. The observation of melt layers in ice cores extracted from our boreholes at SD indicates that high temperatures were already reached at least 10 kyr ago. This is confirmed by the work of Das (2003) who showed that melt layers started to appear about 11 kyr ago after the end of the last ice age.

It is also assumed in our calculations that the ice thickness did not change, because colder temperatures and lower accumulation rate have opposite effect on ice thickness. If the ice were $100 \mathrm{~m}$ thicker, the temperature at the base would increase by about $1^{\circ} \mathrm{C}$. The temperature profiles evolve over time as shown in Figure 2. After 7000 years, half of the temperature jump at the surface has propagated to the bed. The temperature profiles in the sequence are $2 \mathrm{kyr}$ apart, except the first two time-steps are 1 kyr. It takes about $16 \mathrm{kyr}$ for the basal temperature to reach the melting point. The last profile at right is again a steady-state calculation with the bottom temperature fixed at the melting point of $-0.7^{\circ} \mathrm{C}$. In all of the transient calculations, we choose a constant geothermal flux deep in the earth of $69 \mathrm{~mW} \mathrm{~m}^{-2}$. From the sequence of temperature profiles, the one obtained 10 kyr after the initial jump in surface conditions fits best the presently measured profile, at least in the lower half of the borehole. The basal temperature gradients vary from initially -31.4 to $-32.0 \mathrm{~K} \mathrm{~km}^{-1}$, corresponding to the present situation, to $-32.17 \mathrm{~K} \mathrm{~km}^{-1}$ in the future when the bed reaches melting temperature. The temperature profiles are almost linear and almost parallel at great depths because they are controlled by conduction of the geothermal flux. They are curved at shallow depths because they are strongly influenced by surface accumulation. If we converted the present basal temperature gradient directly into a geothermal flux, we would obtain $-70.4 \mathrm{~mW} \mathrm{~K}^{-1}$, thus making an error of about $1 \mathrm{~mW} \mathrm{~K}^{-1}$. To explain the upper part of the borehole in detail would require a much more realistic surface condition history that is not very well known. Additional temperature-profile calculations show that a surface temperature jump even larger than $10 \mathrm{~K}$ or one occurring more gradually and a slightly thicker ice sheet during the last ice age keeps the uncertainty within about $1 \mathrm{~mW} \mathrm{~K}^{-1}$.

\section{DISGUSSION}

The geothermal flux of $69 \pm 1 \mathrm{~mW} \mathrm{~m}^{-2}$ at SD is significantly higher than the typical flux for old stable continental crust, 17-31 $\mathrm{mW} \mathrm{m}^{-2}$ (Sclater and others, 1980), and also much higher than the flux found for Greenland, $51.3 \mathrm{~mW} \mathrm{~m}^{-2}$ (Dahl-Jensen and others, 1998), except for a local caldera structure under a large ice stream in northeast Greenland (Fahnestock and others, 2001), or the average flux estimated for Antarctica of $54 \mathrm{~mW} \mathrm{~m}^{-2}$ (Sclater and others, 1980). More recent work by Shapiro and Ritzwoller (2004) uses a global seismic model and the structural similarity of crust and upper mantle to create a heat-flow map of Antarctica. They show that the WAIS has a heat flow three times higher than that of East Antarctica. For a point in West Antarctica $\left(78^{\circ} \mathrm{S}, 110^{\circ} \mathrm{W}\right)$ they calculate an average heat flow of $110 \mathrm{~mW} \mathrm{~m}^{-2}$ with a standard deviation of $60 \mathrm{~mW} \mathrm{~m}^{-2}$.

This result suggests that the WAIS is based on relatively young crust, which is in agreement with the fact that West Antarctica is a rift system with volcanism (Blankenship and others, 1993; Behrendt and others, 1996, 1998). In a rift system with blocks of crust or sediments of varying thickness, the geothermal flux is normally not only higher but also more variable. In West Antarctica it is likely that in some areas, especially near volcanos, much higher fluxes than measured at SD are possible. Our precise measurement of the geothermal flux at one point is probably only representative of the SD area and its adjacent ice streams (Gades and others, 2000), but it fits well into the global picture envisioned by Shapiro and Ritzwoller (2004).

The elevated geothermal flux probably is the root cause for the dynamics of the WAIS by making it easier to bring the basal ice up to the melting point, without which the great number of active and now relatively shallow ice streams, as compared to East Antarctica, would not have started in the first place.

From our transient temperature calculations it also becomes clear that not only is geothermal flux important for the present basal conditions, but also global warming, which took place after the last ice age $10 \mathrm{kyr}$ ago, influences the basal temperatures thousands of years later at present. A drastic temperature change at the surface is barely felt 1000 years later at the bottom of a $1000 \mathrm{~m}$ deep ice sheet. During the last $10 \mathrm{kyr}$ the surface temperature rose from an ice-age value to the present-day temperature. This translates into an equivalent rise in bottom temperature with a delay of thousands of years. Today's temperatures at the bed of the WAIS, which are at or close to the melting point, are the result of postglacial temperature increases. They are the highest in the last $10 \mathrm{kyr}$ and still rising. The surface temperature may have been temporarily a few degrees higher during the last climatic optimum 8-5 kyr ago, but this effect was too small to be felt at the bottom.

More recent temperature changes like the warm period around $1000 \mathrm{BP}$, followed by the Little Ice Age from 1550 to 1850 and the warming trend during the last 100 years especially in the 1930s and 1990s, show up as temperature variations in the upper part of the temperature profile. However, the density of data points in the upper part is not high enough to allow a precise quantitative reconstruction. They are real because they show up in a number of boreholes. They have no immediate and direct impact on the bottom temperatures. Indirect consequences of further global warming, however, can be quite significant. Breakup of the large floating ice shelves, especially the Ross and Ronne Ice Shelves, will be accelerated in a warming climate by meltwater filling crevasses on the ice shelves and in the shear margins of the ice streams, and by increasing basal melting from warmer ocean currents reaching under the ice shelves. Some ice streams formerly protected by the ice shelves are thinning, speeding up and disintegrating at an accelerated rate similar to the large tidewater glaciers in Alaska, U.S.A., that have catastrophically receded during recent decades (Meier and others, 1994; Rignot, 2002; Rignot and others, 2002). The recent break-up of the Larsen Ice Shelf, the calving of immense icebergs from West Antarctic ice shelves and also the ominous shrinking of the seasonal sea-ice cover may be more than regularly recurring episodes, and could be indicators of more dramatic changes 


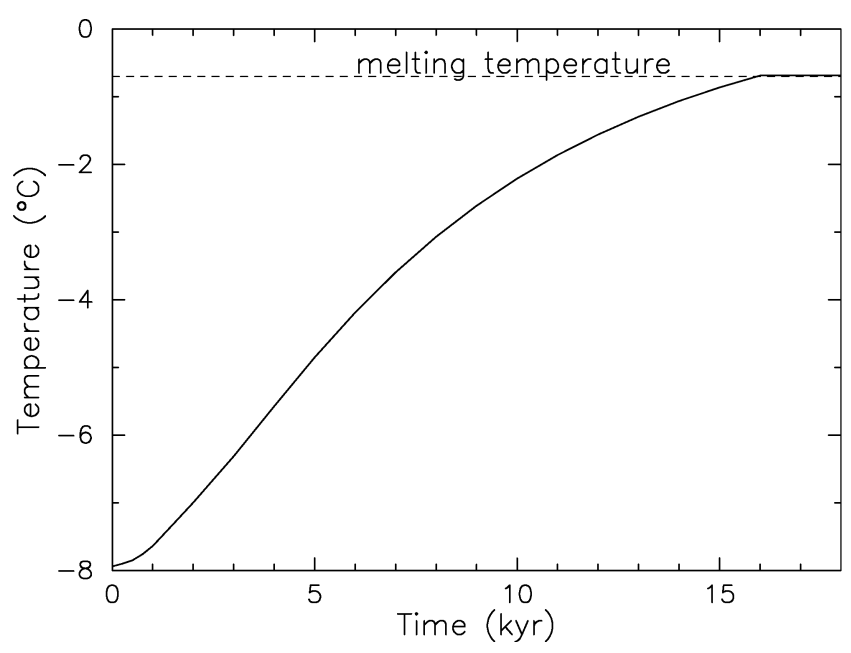

Fig. 3. Bottom temperature for a $1000 \mathrm{~m}$ deep ice sheet with time in kyr after a $10 \mathrm{~K}$ temperature jump at the surface, using a deep geothermal flux that fits best the present observed basal temperature gradient.

ahead. The break-up of the floating ice shelves would not contribute to a rise in sea level per se, but a later consequence could be a speed-up of the ice streams and the disintegration of the entire WAIS, which would increase sea level by about $6 \mathrm{~m}$.

The fact that the base of SD will reach the melting point indicates that it probably melted at the base during the last warm age about 120000 years ago. Extensive melting at that time may have removed older ice, which agrees with the fact that we find no debris in the lowest ice core at SD. In that case, the oldest ice at SD is not older than about 120000 years. The same argument may also apply to other places in West Antarctica. Scherer and others (1998) argue that most of the WAIS must have been open ocean during the late Pleistocene, because of the age of the diatoms found in till samples collected at WAIS borehole sites.

The geothermal flux determined at SD near fast-moving ice streams in the lower reaches of the WAIS may be different elsewhere. A few hundred kilometers further upstream in the catchment areas of the ice streams, subglacial volcanos have been located by aerogeophysical surveys (Behrendt and others, 1996, 1998). It would be reasonable to assume much higher basal geothermal fluxes in the vicinity of volcanos than under SD. They may have produced subglacial water reservoirs where ice-stream surges could have been triggered, similar to glacier surges where water-pressure lubrication plays the decisive role (Kamb and others, 1985). They may continue to provide lubrication water for the active ice streams with very high basal sliding speeds. Basal friction is not strong enough to resist the driving stresses. Friction at the shear margins and, at several bedrock humps, sticky spots within the ice streams make up the difference (Raymond, 1996). At present, the interstream ridges like SD, still frozen at the bed, provide the major resistive forces. The temperature increase with time for the base of SD from the transient calculations is given in Figure 3. The pressure-melting point would be reached in about 6000 years from present. SD and likewise other interstream ridges would be lubricated by meltwater and would start to slide. The ice-stream shear margins, already weakened by shear heating and surface meltwater penetration in a warmer climate, would lose their grip on the ice streams. This would be the long-term scenario for the WAIS to disintegrate as it did in the past (Scherer and others, 1998), but the experience of the last 10-20 years is that things can surprisingly happen much faster. More borehole drilling and ongoing full three-dimensional modeling of the dynamics of the WAIS will reveal interesting details about its future evolution, especially when constrained by borehole measurements of temperature profiles and a better understanding of basal conditions (Hulbe and others, 2001; Tulaczyk and others, 2001; Joughin and others, 2003).

\section{ACKNOWLEDGEMENTS}

I wish to thank B. Kamb for his invaluable support that made this work possible. I admire the incredible perseverance of our field assistants R. Bolsey, A. Blanchard, D. Reusch, A. Bucki, S. Colley, B. Farrow, E. Mueller and H. Schwaiger who participated in the Siple Dome hot-waterdrilling project. This work was supported by a grant from the U.S. National Science Foundation Office of Polar Programs. Antarctic Support Associates and the U.S. Navy provided logistics support.

\section{REFERENGES}

Alley, R. B. and C. R. Bentley. 1988. Ice-core analysis on the Siple Coast of West Antarctica. Ann. Glaciol., 11, 1-7.

Behrendt, J. C. and 6 others. 1996. Patterns of Late Cenozoic volcanic and tectonic activity in the West Antarctic rift system revealed by aeromagnetic surveys. Tectonics, 15(3), 660-676.

Behrendt, J. C., C. A. Finn, D. D. Blankenship and R. E. Bell. 1998. Aeromagnetic evidence for a volcanic caldera (?) complex beneath the divide of the West Antarctic ice sheet. Geophys. Res. Lett., 25(23), 4385-4388.

Bindschadler, R. A., E. P. Roberts and A. Iken. 1990. Age of Crary Ice Rise, Antarctica, determined from temperature-depth profiles. Ann. Glaciol., 14, 13-16.

Blankenship, D. D., R. E. Bell, S. M. Hodge, J. M. Brozena, J. C. Behrendt and C. A. Finn. 1993. Active volcanism beneath the West Antarctic ice sheet and implications for ice-sheet stability. Nature, 361 (6412), 526-529.

Budd, W. F., N. W. Young and C. R. Austin. 1976. Measured and computed temperature distributions in the Law Dome ice cap, Antarctica. 7. Glaciol., 16(74), 99-110.

Dahl-Jensen, D. and S. J. Johnsen. 1986. Palaeotemperatures still exist in the Greenland ice sheet. Nature, 320(6059), 250-252.

Dahl-Jensen, D. and 6 others. 1998. Past temperatures directly from the Greenland ice sheet. Science, 282(5387), 268-271.

Das, S. B. 2003. West Antarctic ice sheet surface melting and Holocene climate variability. (Ph.D. thesis, The Pennsylvania State University.)

Engelhardt, H. and B. Kamb. 1993. Vertical temperature profile of Ice Stream B. Antarct. F. U.S., 28(5), 63-66.

Engelhardt, H. and B. Kamb. 1998. Basal sliding of Ice Stream B, West Antarctica. f. Glaciol., 44(147), 223-230.

Fahnestock, M., W. Abdalati, I. Joughin, J. Brozena and P. Gogineni. 2001. High geothermal heat flow, basal melt, and the origin of rapid ice flow in central Greenland. Science, 294 (5550), 2338-2342.

Gades, A. M., C. F. Raymond, H. Conway and R.W. Jacobel. 2000. Bed properties of Siple Dome and adjacent ice streams, West Antarctica, inferred from radio-echo sounding measurements. f. Glaciol., 46(152), 88-94.

Gow, A. J., H. T. Ueda and D. E. Garfield. 1968. Antarctic ice sheet: preliminary results of first core hole to bedrock. Science, 161 (3845), 1011-1013.

Harrison, W. D., K. A. Echelmeyer and C. F. Larsen. 1998. Measurement of temperature in a margin of Ice Stream B, Antarctica: implications for margin migration and lateral drag. f. Glaciol., 44(148), 615-624.

Hulbe, C. L. and A. J. Payne. 2001. The contribution of numerical modelling to our understanding of the West Antarctic ice sheet. In Alley, R. B. and R. A. Bindschadler, eds. The West Antarctic ice sheet: behavior and environment. Washington, DC, American Geophysical Union, 201-219. (Antarctic Research Series 77.)

Jenssen, D. and U. Radok. 1961. Transient temperature distributions in ice caps and ice shelves. International Association of Scientific Hydrology Publication 55 (General Assembly of Helsinki 1960-Antarctic Glaciology), $112-122$. 
Joughin, I. R., S. Tulaczyk and H. F. Engelhardt. 2003. Basal melt beneath Whillans Ice Stream and Ice Streams A and C, West Antarctica. Ann. Glaciol., 36, 257-262

Kamb, B. and 7 others. 1985. Glacier surge mechanism: 1982-1983 surge of Variegated Glacier, Alaska. Science, 227 (4686), 469-479.

Lliboutry, L. 1963. Le régime thermique de la base des calottes polaires. International Association of Scientific Hydrology Publication 61 (General Assembly of Berkeley 1963 - Snow and Ice), 232-241.

MacAyeal, D. R. and R. H. Thomas. 1979. Ross Ice Shelf temperatures support a history of ice-shelf thickening. Nature, 282(5740), 703-707.

Meier, M. and 9 others. 1994. Mechanical and hydrologic basis for the rapid motion of a large tidewater glacier. 1. Observations. 7. Geophys. Res. 99 (B8), 15,219-15,229.

Müller, F. 1963. Englacial temperature measurements on Axel Heiberg Island, Canadian Arctic Archipelago. International Association of Scientific Hydrology Publication 61 (General Assembly of Berkeley 1963 - Snow and Ice), 168-180

Nereson, N. A., C. F. Raymond, E. D. Waddington and R. W. Jacobel. 1998. Migration of the Siple Dome ice divide, West Antarctica. 7. Glaciol., 44(148), 643-652.

Nereson, N. A., C. F. Raymond, R. W. Jacobel and E. D. Waddington. 2000. The accumulation pattern across Siple Dome, West Antarctica, inferred from radar-detected internal layers. 7. Glaciol., 46(152), 75-87.

Paterson, W. S. B. 1994. The physics of glaciers. Third edition. Oxford, etc., Elsevier.

Paterson, W. S. B. and G. K. C. Clarke. 1978. Comparison of theoretical and observed temperature profiles in Devon Island ice cap, Canada. Geophys. 7. R. Astron. Soc., 55(3), 615-632.

Raymond, C. F. 1983. Deformation in the vicinity of ice divides. F. Glaciol., 29(103), 357-373.

Raymond, C. 1996. Shear margins in glaciers and ice sheets. F. Glaciol., 42(140), 90-102.

Retzlaff, R. and C. R. Bentley. 1993. Timing of stagnation of Ice Stream C, West Antarctica, from short-pulse radar studies of buried surface crevasses. F. Glaciol., 39(133), 553-561.
Rignot, E. 2002. Ice-shelf changes in Pine Island Bay, Antarctica, 19472000. F. Glaciol., 48(161), 247-256.

Rignot, E., D. G. Vaughan, M. Schmeltz, T. Dupont and D. MacAyeal. 2002. Acceleration of Pine Island and Thwaites Glaciers, West Antarctica. Ann. Glaciol., 34, 189-194.

Ritz, C. 1987. Time dependent boundary conditions for calculation of temperature fields in ice sheets. International Association of Hydrological Sciences Publication 170 (Symposium at Vancouver 1987 - The Physical Basis of Ice Sheet Modelling), 207-216.

Ritz, C. 1989. Interpretation of the temperature profile measured at Vostok, East Antarctica. Ann. Glaciol., 12, 138-144.

Robin, G. de Q. 1955. Ice movement and temperature distribution in glaciers and ice sheets. F. Glaciol., 2(18), 523-532.

Robin, G. de Q. 1976. Is the basal ice of a temperate glacier at the pressure melting point? f. Glaciol., 16(74), 183-196.

Scherer, R. P., A. Aldahan, S. Tulaczyk, G. Possnert, H. Engelhardt and B. Kamb. 1998. Pleistocene collapse of the West Antarctic ice sheet. Science, $281(5373), 82-85$.

Sclater, J. G., C. Jaupart and D. Galson. 1980. The heat flow through oceanic and continental crust and the heat loss of the Earth. Rev. Geophys. Space Phys., 18(1), 269-311.

Shapiro, N. M. and M. H. Ritzwoller. 2004. Inferring surface heat flux distributions guided by a global seismic model: particular application to Antarctica. Earth Planet. Sci. Lett., 223, 213-224.

Tulaczyk, S., B. Kamb and H. F. Engelhardt. 2001. Estimates of effective stress beneath a modern West Antarctic ice stream from till preconsolidation and void ratio. Boreas, 30(2), 101-114.

Waddington, E. D. 1987. Geothermal heat flux beneath ice sheets. International Association of Hydrological Sciences Publication $\mathbf{1 7 0}$ (Symposium at Vancouver 1987 - The Physical Basis of Ice Sheet Modelling), 217-226.

Weertman, J. 1968. Comparison between measured and theoretical temperature profiles of the Camp Century, Greenland, borehole. F. Geophys. Res., 73(8), 2691-2700.

Zumberge M.A. and 6 others. 2002. Measurement of vertical strain and velocity at Siple Dome, Antarctica, with optical sensors. F. Glaciol., 48(161), 217-225.

MS received 28 January 2003 and accepted in revised form 13 January 2004 